\title{
A Comprehensive Look into the instruction of Listening Skill in Academic English Programs: A Case Study of two State Universities in Iran
}

\author{
Hamidreza Babaee \\ Faculty of Human Science and Literature, University of Guilan, Iran \\ E-mail: hreza86b@gmail.com
}

Received: 01-04-2017

Accepted: 29-04-2017

Published: 30-04-2017

doi:10.7575/aiac.ijels.v.5n.2p.112

URL: http://dx.doi.org/10.7575/aiac.ijels.v.5n.2p.112

\begin{abstract}
The study reported here thoroughly investigated the instruction of listening skill in academic English programs. This was researched through a semi-structured interview. In this regard, in order to obtain a picture of listening requirements across the academy, data were collected from two different state universities of Iran. To compile the data, five listening lecturers from these two universities were invited to participate in the study. Topics investigated through the interviews included; the importance and objectives of English as a Foreign Language (EFL) listening in university study, the nature of listening in academic English programs, quantity and type of listening prescribed on courses, the integration of listening with other skills, and the evolution of changes in students' listening requirements and practices. The analysis of the interviews revealed the two types of the courses; academic English-oriented courses and general English-oriented courses, each of them having their own perspectives regarding the various aspects of the listening. Regarding the changes in students' practices, two types of transformations were found; transformation of the processes from bottom-up to top-down and transformation of the materials from textbook-oriented to more internet-oriented perspectives. The findings of the present study suggest some practical implications for the EFL students and teachers. In this regard, students need to equip and accustom themselves with more interpretive skills of listening and internetoriented materials in their classes. Teachers are also required to balance between different types of skills and course materials in their classes according to their students' needs.
\end{abstract}

Keywords: Academic listening, listening requirements, semi-structured interview

\section{Introduction}

Listening is one of the important and necessary communicative skills for us in our everyday life. Without this skill life will be very difficult for us and will require a great deal of adaptation. Listening has significant roles in all aspects of our life from childhood to the last days of our life. Paul T. Rankin former Supervising Director of research and adjustment for the Detroit public schools conducted an investigation on the four communication skills (Iwankovitsch, 2001). He found that the average person spends $9 \%$ of his time writing, $16 \%$ reading, $30 \%$ speaking, and $45 \%$ of his time, listening. Listening one of crucial components of spoken language processing without which there is no spoken language. Listening is also interconnected with various areas of investigation and development. It is reasonably germane in humanities and applied sciences such as linguistics, education, business and law, and in social sciences such as anthropology, political science, psychology and sociology (Rost, 2011).

There is a large variety of different types of listening in real life (e.g. listening to announcements in stations, airports, etc. listening to the radio, participating in a conversation face-to-face, watching TV, participating in a meeting, seminar or discussion, taking part in a lesson, participating in a telephone conversation, among others) (Alonso, 2012). Two broad types of academic and conversational listening are also known in the literature. Conversational listening happens as forms of interactional and transactional exchange of talk among two or more people. Academic listening usually denotes to listening to lectures or negotiations in academic contexts (Jeon, 2007). Richards (1983) suggested taxonomy for academic listening at odds with conversational listening; implying that the listening skills necessary for academic tasks may need to be discriminated from conversational listening skills. In his taxonomy, skills such as; ability to identify purpose, scope of listening, and topic of lecture, ability to follow topic development, and ability to infer relationships were of paramount importance. As a matter of fact the discrimination between the two types can be rationalized as they occur in different contexts requiring various skills of listening.

A lot of studies have been conducted on the domain of academic listening skill from various specific perspectives in the academic contexts (Buck, 2001; Dudley-Evans, 1994; Flowerdew \& Milller, 1997; Smidt \& Hegelheimer, 2004). In this study, the researcher has implemented a qualitative framework to reveal the overall requirements and expectations of listening in Iranian academic context as the importance, objectives and the nature of listening in university study, 
quantity and type of listening prescribed on courses, the degree of integration of listening with other skills, and the evolution of changes in students' listening requirements in order to inform the students and teachers about these requirements and remove some ambiguities and misunderstandings among them regarding the listening skill in English university programs.

\section{Literature Review}

\subsection{Academic Listening}

Academic listening is a type of listening that occurs in university English programs. It includes different acts of listening for the purpose of comprehension of the material. It is characterized by one-way transactional language that intends to convey information and knowledge (Chaudron, 1995; Flowerdew, 1994). According to Flowerdew (1994), the knowledge for academic listening is pertinent to specific subject matters that are related to the topics of lectures or discussions dealing with listeners' professional ground works. Due to this feature of academic listening, a listener in academic situations is supposed to build up an intellectual groundwork for a coherent mixture of information and for a regular incorporation of the new information into accessible cognitive organizations for successful learning (Imhof, 1998). According to Imhof (1998), academic listening is "characterized by a certain degree of asymmetry between the speaker and the listener(s) on the knowledge dimension due to the information gap between the listener and the speaker" (pp. 84-85). Power (1986) highlighted the importance of note-taking as the skill of retaining information that would be needed for only academic listening.

\subsection{Academic Listening vs. Conversational Listening}

In the literature, academic and conversational listening has always been distinguished from each other. From these divergences, it can be assumed that academic listening has some aspects in comparison to conversational listening. In this regard, Flowerdew (1994) pointed out that the distinctive aspects between the two kinds of listening can be expounded by the divergences in both degree and kind. In the case of the differences, three differences such as the kind of needed background knowledge, the ability of unraveling main points and neglecting others, and the frequency of turn-taking were suggested as the categorization scheme between the two types of listening. Flowerdew (1994) stressed that the required knowledge for academic listening is applicable to specific subject matters because subjects of lectures or tutorials are intimately associated with listeners' specialized ground works. Hansen (1994) highlighted the importance of figuring out the important points of the discourse and distinguishing major points from minor points as the key to successful academic listening. Richards (1983) also pointed out that the skill to discriminate significant information and disregard other information has a superior precedence over other skills required to develop academic listening. even though a skill to make a distinction between what is pertinent to the main point and what is less appropriate is required for any kind of listening for understanding (Flowerdew, 1994), However, this ability is conceivably more indispensable for academic listening than for conversational listening (Jeon, 2007). Chaudron (1995) stated that academic listening inclines to be reasonably cautiously designed in terms of the content; therefore, turntaking arises only if questions are asked from a lecturer or fellow listeners. On the other hand, turn-taking in conversational listening is evidently indispensable to sustain interactional exchanges of the information and maintain what Malinovski (1923) termed "phatic communion".

According to Flowerdew (1994), With regard to differences in kind, two differences can be realized: strategies employed by listeners, particular skills needed for academic listening. O’Malley, Chamot, and Kupper (1989) provided an in depth list of L2 learners' self-reported strategies for listening in academic contexts. They stressed that L2 listeners have a tendency to employ various and multifaceted strategies in academic context. Note-taking is a renowned example of strategies that L2 listeners use for academic listening (e.g., Chaudron, 1995; Chaudron, Loschky, \& Cook, 1994; Dunkel, 1988). With reference to skills needed for academic listening, Flowerdew (1994), for example, pointed out that the skill "to integrate the incoming message with information derived from other media" (pp. 11-12), can be required only for academic listening. The other skills such as, note taking, are also associated with the academic listening. Imhof (1998) suggested the critical features of academic listening distinguishing it from other kinds of listening. In this regard, he enumerated there aspects namely; transactional aspect of academic listening, the asymmetric interface between a speaker and a listener, the asymmetric communicational facet of academic listening dealing with the social distance among the lecturer and other fellow students, and long periods of time needed for conveying the information.

Although there are some common aspects between academic listening and conversational listening, academic listening has its own idiosyncratic aspects (Jeon, 2007). Over the last decades some studies have been conducted on these aspects. For example some researchers have examined the effects of discourse structures on academic listening (e.g., Dudley-Evans, 1994; Olsen \& Huckin, 1990; Tauroza \& Allison, 1994; Young, 1994). In the domain of speech rate, some of researchers (e.g., Griffiths 1990; Zhao 1997) have investigated the impacts of speech rate on the comprehension of speech in the academic context. The strategies and sub-skills required for listening in academic context have also been subject to investigation (e.g., Bacon, 1992; Lynch, 1995; O'Malley, Chamot, \& Kupper, 1989; Vandergrift, 1996). Overall in recent decades, the academic listening has been investigated from the various perspectives. However, to my knowledge, there has not been conducted any study in a comprehensive and qualitative manner revealing some inside-the class and out of the class concrete requirements for the students. Thus, it is important for students in academic context to be made aware of these requirements. This study has tried to shed light on these requirements and reveal important information regarding the importance and objectives of listening in university study, 
the nature of listening in university study, quantity and type of listening prescribed on courses, integration of Listening with other skills, and the evolution of changes in students' listening requirements and practices.

\section{Method}

\subsection{Design}

The study has a qualitative design. It employs the tools of qualitative inquiry. According to Dornyei (2007), "Qualitative research involves data collection procedures that result primarily in open-ended, non- numerical data which is then analyzed primarily by no-statistical methods" (p. 24). The study has made use of one research method: Semi - structured interview with academic staff for gathering the data needed for the study.

\subsection{Instruments}

In order to get a comprehensive picture of listening requirements in the academic context, the current research drew on semi-structured interviews with academic instructors. This kind of interview allowed the researcher to pursuit the scheme identified as the 'discourse-based interview' (Odell, Goswami \& Herrington, 1983). Such a procedure involves discussion with interviewees about specific text samples - in this case, the course materials provided by the lecturers. Interviews were conducted with the five participating lecturers. Prior to the interviews, a list of questions was sent to interviewees (Appendix). The interviews were divided into two main phases, covering:

- general listening requirements on courses

- listening requirements on specific assessment tasks

All interviews were audio-recorded, and transcribed. The main themes and ideas to emerge from the instructors' commentaries are presented in section 4. In some parts, the interview excerpts appearing in this research are the major word for word transcriptions of the interviews. In some cases, some insignificant superfluous features (e.g. false starts, hesitations, fillers and the like) are removed for the purpose of making the information contained in the interviews more clear and transparent.

\subsection{Participants}

In order to obtain a picture of listening requirements across the academy, data were collected from two different state universities of Iran. To compile the data, five listening lecturers from these two universities were contacted and invited to participate in the study. The number of interviewees was rather small so that the qualitative data could be examined more deeply and meticulously. It is noted that, interviewing with a small number of participants is a common practice among qualitative researchers (e.g. Erkaya, 2009; Love \& Simmons, 1998) so as to more profoundly examine the data. Furthermore, the findings of interviews had already reached a state of saturation and repetition and new findings were unlikely to emerge out of extra number of interviews. Besides, since the aim of these interviews was to shed light on the areas of assessment and course requirements in the academic domain, it was necessary that interviewees participate with their complete willingness in order to cooperate with the researcher maximally. All of the lecturers were also observed to prescribe textbook to their students in their courses. One of the textbooks prescribed named, Tactics for listening, was common textbook prescribed among two of them. While interviewing with them, lecturers' voices were also recorded in order to be further transcribed and used as evidences for the various parts of the research.

\subsection{Data analysis and Procedure}

The study was primarily qualitative in nature including the use of qualitative research instrument: a Semi - structured interviews with academic listening lecturers. The study was carried out in following steps: to compile data required for the study, interviews were conducted with the five participating staff. Lecturers from the 5 selected listening courses were contacted and invited to participate in the study. Participation involved the passing on of course a printed schedule of questions related to the listening and assessment materials contained in interview (Appendix); then, making the appointments with the instructors, the interview was conducted with them and the lecturers' voices were recorded for the further analysis. Finally, the voices were transcribed and analyzed through using the coding method. In this regard, first, initial coding was carried out and the relevant information is highlighted. Then, in the second-level coding, the all codes identified have been listed according to the related respondents' accounts and eventually the related commentaries were provided and discussed that were significant for the purpose of the research to get the comprehensive picture about English as a Foreign Language (EFL) listening in academic English listening courses.

\section{Analysis and Findings}

To gather the data required for the study, investigation was made of the types of listening tasks required of students in undergraduate study in a range of listening courses in two universities of Iran, namely, University of Guilan and International University of Imam Khomeini in Qazvin. As discussed, a total of 5 listening courses were investigated. In universities investigated, no isolated listening course was observed, instead the courses were observed to be the integration of listening and speaking skills. In these listening and speaking courses in terms of the manner of teaching, in some cases, these two skills were observed to be taught and practiced distinctively, and at the other cases, they are instructed in an integrated manner. Whatever the manners were, in this study, it has been tried to take both the issues of isolation and integration into consideration. From five courses investigated, three courses were from University of Guilan and two of them were from International University of Imam Khomeini in Qazvin. Four types of textbooks with 
their different levels were observed to be utilized in these courses. Table 1 illustrates the name of the textbooks along with their levels used in each of these courses and the name of the university where the courses were held. It is noted that the abbreviations to each university and textbook is provided in the table and instead of the lengthy introduction of each lecturer and textbook in the analysis, the abbreviations are used.

Table 1. The courses investigated in the study

\begin{tabular}{|c|c|c|c|}
\hline No & University & Textbook title & Textbook level \\
\hline 1 & University of Guilan (UI) & $\begin{array}{l}\text { Real Listening and } \\
\text { Speaking }(R L S)\end{array}$ & $\begin{array}{l}\text { B1: pre - intermediate } \\
\text { B2: intermediate, upper-intermediate } \\
\text { B3: Advanced }\end{array}$ \\
\hline 2 & University of Guilan (UG) & Mosaic Series (MS) & $\begin{array}{l}\text { Mosaic } 1 \text {, Mosaic } 2 \\
\text { Listening and speaking }\end{array}$ \\
\hline 3 & University of Guilan (UG) & Lecture Ready (LR) & $\begin{array}{l}\text { Level 2, intermediate } \\
\text { Level 3, high intermediate }\end{array}$ \\
\hline 4 & $\begin{array}{l}\text { International University of } \\
\text { Imam Khomeini (IUIK) }\end{array}$ & $\begin{array}{l}\text { Tactics for Listening } \\
(T L)\end{array}$ & Developing level, Expanding level \\
\hline 5 & $\begin{array}{l}\text { International University of } \\
\text { Imam Khomeini (IUIK) }\end{array}$ & $\begin{array}{l}\text { Tactics for Listening } \\
\text { (TL) }\end{array}$ & Developing level, Expanding level \\
\hline
\end{tabular}

\section{1 Importance and Objectives of Listening in University Study}

The first fundamental finding from the interviews was that listening in some form was prerequisite for the comprehension of material. One of the instructors stressed that it was the listening skill that underlay the process of getting input in academic context. Thus, the first lecturer in IUIK teaching listening using TL textbook in his classes saw listening as a difficult and important skill that provide the common thread for getting information on various subjects on his course:

I think it is one of the most difficult skills to acquire; it is a kind of skill which is required for all Learners weather second or foreign language learners to have a good knowledge, to somehow gain knowledge because this is a kind of a way of acquiring and getting input. I believe it is the most important skill that learners have to acquire and it is somehow according to Buck (2001) the most difficult skill. (Textbook: Tactics for Listening)

The lecturer of the $R L S$ textbook from UG considered listening skill from communicative perspective and affirmed the importance of interaction and communication in his classes.

In my classes, there are lots of interaction among the students, teacher and student, student and student and lots of classroom conversations. (Textbook: Real Listening and Speaking)

For him the key skills required in the process of interaction and communication were of paramount importance:

So what is important is the ability to express one's views and the ability to follow what is mentioned by other students, by the teacher and by the people when they watch the video or listen to the material in English, so they can interact and understand.

For the LR instructor, preparing students to be able to deal with academic lectures and discussion in an academic context was one of the more important objectives on her course.

My listening course intends to enable students to make the transition to successful encounters with real life academic lectures and discussions by familiarizing them with the Strategies for Academic Listening, Notetaking, and Discussion. More specifically, the main objective of the course is to prepare students to deal with academic lectures and discussion with skill and confidence. (Textbook: Lecture Ready)

The other informant from IUIK referred to Krashen's i+1 and made a comparison between L1 and L2 in order to confirm the significant importance of listening as a skill through which comprehensible output would be produced over time. 
Listening is a pre-requisite for speaking, so when you want to teach speaking you start with listening. According to Krashen's Monitor Model, there are five hypotheses which one of them is about input, i +1 , so input is very important. If teachers expect students to have output, they have to give them comprehensible input because they are like children, you know when children are born we don't expect them to talk. They go through the silent period, so they receive enough input until they can produce output. (Textbook: Tactics for Listening)

Whilst not emphasizing Listening skills and strategies to quite the same extent, almost all instructors spoke of the development of key skills and sub-skills in listening as one of the more important objectives on their course. For example for one of the lectures of UG using $M S$ as a text book in his classes, critical thinking skills were one of paramount importance in his course.

In my syllabus, I am concerned with teaching functions of the language along with the strategies of listening, we have some sections on teaching vocabulary items and some activities that appeal to students' critical thinking and ask them to actually stress believes, attitudes, and ideas they need to think about something. Along with these issues we have critical thinking based activities, critical thinking informed activities and also functional aspects of the language. (Textbook: Mosaic Series)

In this case, for the other instructor in UG using LR textbook in her listening course, the development of key skills and strategies required in listening to academic lectures was one of the more important objectives on her course.

Students learn two types of listening strategies: (1) strategies for independently preparing for each stage of the listening process - before a lecture, during a lecture, and after a lecture and (2) strategies for recognizing "lecture language" - the discourse markers, speech features, and lexical bundles that lecturers across disciplines commonly use to guide students in taking in information. (Textbook: Lecture Ready)

In this regard, for her, not taking is one of the effective ways through which students can get the gist of the material delivered by academic lectures.

In addition, note taking strategies focus the students' attention on the accurate and concise recording of material delivered during a lecture. They learn that effective note- taking is the cornerstone of effective studying.

Mention was also made in interviews about the importance of vocabulary learning and the ways of learning and teaching it through listening and speaking skills. For example, one of the lecturers of the UG insisted on the learning the academic-related vocabularies throughout the listening course and the other instructor from this university confirmed the issue of practicing the vocabularies, the meaning of which the students don't know, through and during the listening practice

The students learn a body of general academic vocabulary as well as vocabulary relevant to each field of study which is then practiced throughout the listening and speaking process. (Textbook: Lecture Ready)

If there are vocabularies, the meaning of which they don't know, I would provide them with the list of the vocabularies and sometimes put them on the board and ask some students to taught, make sentences and explain the use of these vocabulary items. So to make it, the repetition of the material, in order to give them opportunity to practice the listening. (Textbook: Real Listening and Speaking)

In the case of pronunciation, one of the informants from UG affirmed the importance of pronunciation practice in a listening course and stated that it is necessary to familiarize students with different varieties, accents and pronunciations of English and in this case, learning the native-like pronunciation, was one of the significant objectives of his course.

I am trying to help students to recognize different patterns of accents and pronunciations. I mean different speakers have different varieties of English. Sometimes British English, sometimes American English, sometimes Canadian, Australian and even world English, Japanese speakers of English for example. So there are varieties of English, but mainly my focus is on British English as book suggests. (Textbook: Real Listening and Speaking)

The other instructor from IUIK put the great emphasis on the integration of listening and speaking together. Although in terms of syllabus, he was not specifically clear about the objectives of the listening in his course, he made it clear that, the ultimate goal of his course was developing speaking through listening.

The ultimate goal of listening is speaking, that is my ultimate purpose of listening, because if they have enough input and listening, they can after sometimes automatically talk. (Textbook: Tactics for Listening) 
The main picture to emerge from these commentaries was that varieties of objectives were sought in these courses. From some of informants, it was generally felt that what was crucial in their course was for students to come away with a good experiences and knowledge of foundational strategies and skills of listening. Whilst, a number of theme emphasized the issues such as; vocabulary learning through listening, listening to academic listening, pronunciation and interaction.

\section{2 Nature of Listening in University Study}

As a way of facilitating discussion around the nature of listening in the interviews, it was decided to provide a list of possible listening skills and sub-skills drawn from the literature (Harmer, 1990; Richards, 1985), (Appendix) and to ask instructors to comment on which of these they believed were germane to study to their course. A preliminary analysis of commentaries expressed by informants regarding the nature of listening revealed a fair amount of variation in the perceptions of academics across the listening courses. It was noted, for example, that three of instructors who were more academic English - oriented in their listening practices, attested the utility of more interpretive ways of coping with listening input. Whilst others, more general English- oriented instructors, insisted on the combination of both bottom up and top-down ways of processing listening stimuli. The following are a sample of the responses from the first group, academic - oriented listening instructors who were from the UG. For these academics, the focus was squarely on the more interpretative listening skills. Among those on the list, the note taking skill had particular reverberation. One of the lecturers from this group focused on the academic type of listening and verified the efficacy of more interpretive skills to be developed by the students.

I think for academic development, writing summary of what you listen to is very useful. Taking notes is also useful. Others would be good but if they help students write a good summary of what they listen to. Something about getting the gist of the material is not mentioned here. Identifying the main ideas that are also very important. Identifying the position of the speaker is not also mentioned here. For academic purposes, listening is more than just listening, it's also related to learning. So listening for the purpose of learning something new, one of the major aims at the university. I don't see it here. (Textbook: Real Listening and Speaking)

He also corroborated the importance of intonation in terms of helping listeners to detect the position of the speaker towards the topic of the talk.

I mentioned something about the position of the speaker, then one way to find out it and detect the attitude of the speaker to our subject matter is through intonation that has several functions such as; discourse function, attitudinal function, grammatical function, to signal informational structure.

In a similar vein, second and third informants from the UG also affirmed the importance of inferential type of listening and emphasized that through this kind of listening skills students can go through the stage of academic improvement. For the second informant who was using Mosaic Series as the textbook in his course what was matter, was listening for the purpose of exchanging the information in the initial sessions of the course and then pragmatic kind of listening at later sessions:

Initially, we are mainly concerned with exchange of information in the very first sessions. But as the course proceeds, we are mostly concerned with making inferences, giving reasons, justifying the answers and understanding pragmatics. In some conversations of the book, the requirement is to understand the intended meaning of the speaker, how we can be sensitive to the body language and make use of paralinguistic futures to understand what a given speaker said. (Textbook: Mosaic Series)

Thus, for him, academics types of listening skills are of significant importance:

Actually most of these skills are covered in the textbook, but, in particular some of the skills are more highlighted. For example, evaluation, to take notes and to comprehend class lectures. These are mainly emphasized because these are techniques that students need in academic context and are more important in this context.

In this case, the third instructor from this university prescribed two types of specifically academic lecture - related listening strategies into her course that would enable and prepare students to cope with academic lectures.

Students learn two types of listening strategies: (1) strategies for independently preparing for each stage of the listening process - before a lecture, during a lecture, and after a lecture and (2) strategies for recognizing "lecture language" - the discourse markers, speech features, and lexical bundles that lecturers across disciplines commonly use to guide students in taking in information. (Textbook: Lecture Ready)

The conclusive picture to reveal from these commentaries was that the significant type of listening in these more academic English - oriented listening courses was that associated with the 'inferential' comprehension of material. 
From these informants, it was generally felt that what was crucial in their listening course, was for students to come away with a good working knowledge of pragmatic ideas and concepts - and not to be spending too much time for 'verbatim' or word for word understanding of the input. On the other hand, the general English - oriented listening instructors who were from the same university using the same textbook, TL in their classes, insisted on both literal and inferential types of listening. One of them pointed out that:

It depends on the kind of task. If it require literal comprehension, they need to pay attention to the detail and do not need to just listen and understand inferential comprehension. On the other hand, students need to have background information and activate their schemata and top down processing to get the whole idea, to get the gist. Generally in my listening course, extracting specific information, getting the general picture, comprehending class lectures, taking notes, evaluating what is redundant and what is relevant, are all important. However, I don't think confirming expectation about tasks and following instruction are important. (Textbook: Tactics for Listening)

He also took account of the notion of the Vygotsky's Zone of Proximal Development theory and highlighted the role of interactive kinds of listening skills and substantiated them as ways of improving students' ZPD that finally would lead them to the acquisition of input:

Interacting with teachers and peers would go to under the heading of dynamic assessment. If they have a kind of interaction with the teachers and their peers, they will get the better understanding of the oral text and I think they can improve their ZPD that I think it is very important for them to have their interaction and this would generate input enough for the other learners as well. It's a kind of comprehending input and interaction that eventually increases the acquisition of the input.

Similarly, for the other general - oriented informant, the integration of both processes was important. In addition to it, a utilitarian conception of listening was emphasized by this instructor. In this case, the focus was to draw on linguistic resources for a different practical purpose - namely to get a job by listening to a variety of texts.

In my listening course, it's a combination of both top down and bottom up knowledge that is important. In the case of listening skills, I think some skills are not included in the list, for example, the ability to get job. Because, the purpose of learning foreign or second language for students is ability to get job, I don't see it here. Generally speaking, all of these skills are important. (Textbook: Tactics for Listening)

A common theme to emerge from these general - oriented commentaries was that in one's teaching, the more combination of both 'literal'- based and 'inferential'- based skill areas were taken into consideration to a great extent, and that much of what students were expected to do simply assume an understanding of both literal and pragmatic comprehension of input. Whilst there was a variation in the case of listening skills required on courses, were perceived general agreement among instructors about the importance of sub-skills and the ways that students needed to engage with these sub-skills.

I thing sub-skills are all important as a whole at the package. If you are teaching based on communicative approach, then you focus on the overall things than specifics, they can't be isolated and for each session you work on one thing that doesn't work ideally. (Textbook: Real Listening and Speaking)

When it comes to the sub-skills, we have purpose and scope of listening that are very important, making inferences is also important. Of course in the book we have covered most of them. Expect a few of them such as; ability to recognize irrelevant matters such as; Jokes, digressions and meandering. Some of them are further emphasized in some activities but most of them are covered in classes, specifically in academic types of activities. (Textbook: Mosaic Series)

They are all included in the listening sub-consciously. For example, sometimes the lecture is divided into two sections and the discourse markers enable students to be aware of the structures of the text and also be able to analyze the text. In the case of inferring relationships, if students are supposed to decode the kind of oral input, they have to infer the relationships between the people involved in the text. (Textbook: Tactics for Listening)

\subsection{Quantity and Type of Listening Prescribed on Courses}

Along with variation in the nature of listening on courses, a fair amount of discrepancy was noted regarding the amount and types of listening prescribed in each listening course. The differences perceived here were mainly between courses. Such differences were quite noticeable, for example, in the quantity of listening anticipated from listeners. In some 
listening courses, instructors spoke of the need for students to do 'substantial' listening on their courses, and generally to go beyond the set listening:

In my classes, I do not rely on just textbook, my class is very natural. I give them oral tasks in advance, I choose a topic from internet and give it to them and ask them enough material for the topic and come to the class with pre-preparation, many come to the class and talk about the information. I ask them to listen to the $\mathrm{BBC}, \mathrm{VOA}$ and there are many challenges to news and views in satellites. I ask them recall the information and bring it to me. (Textbook: Tactics for Listening)

The main textbook is real listening and speaking that is based on communication and developing skills for listening and speaking. But lots of other activities, lots of listening and watching, I mean spoken English. So we have variety of tasks variety of spoken English. I emphasize listening not just in the classroom, lots of assignment for them to do. At times I would require them to prepare things and search for the material that will be part of the evaluation of the course. (Textbook: Real Listening and Speaking)

The textbook is Mosaic one and two. Along with textbook we use other activities, podcasts, other videos and audio recorded materials. Students need to listen to material and engage in the listening activities. They watch the video podcasts that is a speech of the native speaker and then try to summarize and share the ideas. When we have such tasks and activities in the course, many of them require some listening in advanced, so in the classroom we are not able to cover all types of the listening activities, so some of them are to be handled at home. (Textbook: Mosaic Series)

Students will be presented with 10 filmed lectures that are the centerpiece of each student book chapter. Lectures can be viewed with subtitles and targeted listening exercises are to be done following that. They are expected to put in a good deal of time outside of class on their English. If they set aside between one and two hours every day to spend on English, they should have no problem completing assignments. (Textbook: Lecture Ready)

For the other instructor form IUIK using TL in his course, in addition to prescribing the abundant number of materials for listening that go beyond the classroom listening, seeking out a variety of authentic and encouraging material was an indispensable part of engaging the students with the course:

I give a bunch of material such as podcasts and every day conversation that trigger a better comprehension, to them to work and listen. They have to be inundated by the number of listening material I give to them. It's a kind of flooding the input with the listening material. The material should be authentic and related somehow to the students' background, although it is important to choose from encouraging and motivating material. (Textbook: Tactics for Listening)

Four of informants in interview were quite precise about the time that should be devoted for listening and they went on to explain that how much listening is required from students in and outside of the classroom.

There is a syllabus by ministry of education, but apart from syllabus, students must listen at least 6 hours every week to the news and views, that is out of class activity and bring it to me when they come to the class. (Textbook: Tactics for Listening 1)

At least one third of each session is devoted to listening skill, because if we don't understand the speaker, how can we give a good speech or present something successfully. I usually recommend students to listen regularly; I mean they need to listen every day, because they are not exposed to authentic texts in high schools. (Textbook: Mosaic Series)

This course is set up to give students as much exposure to and practice actually using the language as is possible in an undergraduate program. They are expected to spend at least one hour outside of class for each hour in class. This will be easier if they write this hour into their daily schedule, rather than leaving it to the last minute. (Textbook: Lecture Ready)

I would say more than seventy percent of the time in the conversation class for the conversation course should be allocated to the listening comprehension. I think at least there should be around two or three hours every day for students for listening. (Textbook: Tactics for Listening 2) 
Although one of the instructors was not clear about the time that students are required to put in listening, He insisted on more listening than speaking and integration of both skills rather than isolation of them in his course.

Because it's a course of listening and speaking, ideally, students would need a lot of listening, a lot of interaction that would be based on listening. So one of the critiques against my class would be more listening rather than speaking. I have not got separate activities that have listening in isolation, I encourage having interaction. For that purpose, they need to listen a lot both in the classroom and outside of the classroom. (Textbook: Real Listening and Speaking)

He also challenged the notion of regular listening outside of the classrooms because of some of the limitations existing in the context of foreign language teaching and learning in comparison with that of second language teaching and learning.

You need to be realistic. It is a foreign language teaching and learning context. Some students are of dormitories. They have no access to any listening material and when they are in the campus, they have to attend to their classes. They don't have that much time. I do advise them to have variety of activities, regular listening would be useful, but I mean that they have the opportunity to listen to their teachers here and listening materials. (Textbook: Real Listening and Speaking)

In the case of type of material, one of the instructors said that he took the level and needs of the students into consideration in choosing the relevant and motivating material and as a kind of negotiated syllabus, he council with the students about the appropriate materials required for the class.

Based on students' levels and needs I choose material, Sometimes I choose from the internet or from books available in the market. I combine these materials and the assessment would be out of them. Sometimes I council it with students and ask them to bring their materials, because I believe that when they bring the material, they get a kind of motivation to listen and understand the material, However, the ultimate decision is taken by me. (Textbook: Tactics for Listening)

\subsubsection{Integration of Listening with Other Skills}

Because the courses investigated were normally conversation courses, the integration of listening and speaking where the principle requirement of these courses as well and all of the informants also agreed upon the notion of integrating listening with speaking and other skills. For example, one of the instructors from UG attached special significance to students being able to "write summary of a section" and to "express what was the last point in the conversation or lecture", For him, such abilities related to a crucial part of the training students needed to be vigilant listeners - namely the ability to listen and interpret the material thoroughly and diligently.

I would ask students to write the summary of a section from listening input. Sometimes I would play the section of a listening from the book and ask everybody to listen very carefully and name some of them to tell me what the last point was. I have not got separate listening activities, nor speaking activities in isolation. I encourage them to have interaction. (Textbook: Real Listening and Speaking)

For the other instructor from this university, in addition to the integration of listening and speaking, integration of all four skills was important.

Specifically in Mosaic series, we have an integration of the skills. There are some written exercises, reading exercises, but we have a combination of these skills. I mean when we have writing exercises for example, it leads to a kind of listening task or when there is a reading assignment there is a need to read something and then that is a fuel for a kind of discussion or debate in a given topic. So skills are integrated and we are not concerning with speaking and listening in isolation. (Textbook: Mosaic Series)

More decisively, the third instructor from the UG also highlighted the prominence of integration of listening with speaking in terms of enabling students in acquisition of general academic vocabularies and discussion strategies required in speaking through listening that would lead students in the process of classroom speaking and participation.

To develop the speaking ability, the students learn a body of general academic vocabulary as well as vocabulary relevant to each field of study which is then practiced throughout the listening and speaking process. They will also learn discussion strategies. These strategies clue students in to university classroom expectations for participation. They also allow students to practice the language necessary for becoming an active member of a classroom discussion. (Textbook: Lecture Ready) 
Other informants from IUIK using the same textbook in their course emphasized the integration of listening with speaking and writing skills through utilizing some activities such as transcription and interview. One of these lecturers, for example, said she advised students to transcribe and give explanation about what they listen. The other lecturer from this university insisted to her students that they should devote their time to summarizing and speaking about the input that they receive.

Sometimes I ask students to listen to material and speak about they acquired. Sometimes I ask them to listen to oral input and then try to summarize it in a piece of writing. That would be integrating listening and writing skill and listening and writing tasks. (Textbook: Tactics for Listening 1)

Transcription and interview would be kinds of integrated practices. You know, sometimes I ask them to listen and write that is the integration of listening and writing. At the same time they can develop two skills. I also ask them to listen and give explanation about the content of the tape or the clip. (Textbook: Tactics for Listening 2)

\subsubsection{The evolution of changes in students' listening requirements and practices}

A last area covered in this summary of interview results is instructors' opinions of changes in students' listening requirements and practices on their courses. Interestingly, the perceived changes commented by informants were a kind of transformation from one situation (or situations) to the other situation (or situations). In short, comment was expressed by one of informants about the transformation of listening process from literal to interpretive forms as the course proceeds:

From the beginning we have a particular syllabus and are concerned with exchange of information and activities that are more factual, But as the course proceed, the material tends to be complicated and the activities tent to be inferential and in line with critical thinking skills. I mean they need to study the material in advance and share the ideas. (Textbook: Mosaic Series)

The view expressed from one of the lecturers from IUIK represented a clear contrast. For this lecturer, the transformation was relatively reverse. A common theme here was that in his course, the more 'literal'-based listening comprehension was taken into consideration as the course proceed, and that much of what students were expected to do simply assumed an understanding of literal understanding of the material at the expense of inferential comprehension to some extent:

In the beginning, because I was not experienced enough, I mostly focused on top down listening skills and then later on as my PHD dissertation was about, I mostly needed to work the bottom up processing tasks. (Textbook: Tactics for Listening)

For the other lecturer from this university, the transformation of situations was of renovation kind. In the case of materials and assessment, He stated that over time he renovated from more textbook - oriented to more internet oriented view:

I used to teach more from books, but now I have a change from book to internet. In addition to textbook we have a plenty of information regarding listening and speaking from internet, because I believe in technology, you know every minute technology is changing. (Textbook: Tactics for Listening)

Similarly, the lecturer who was using Real Listening and Speaking in his classes, pointed out that he updated his course to include not only more new materials but also new methods of teaching.

The focus changes but not the all things. I try to keep pace to changes. I try to be up to date. I look for new materials, I myself sometimes provide them with new materials in terms of listening, watching the material which are suitable or related to listening and new methods of teaching. (Textbook: Real Listening and Speaking)

For him Change was indispensable part of the course without which effective exposure to the authentic input would not occur.

The change of the material is a kind of must. I mean variety of activities and change of books is essential. Because you can't do the same thing each and every term, because lots of things would change, the contact people have in English, the exposure to English is not comparable when you consider ten or twelve years ago, the level of English of students differs greatly and this is sometimes a problem. (Textbook: Real Listening and Speaking) 


\section{Discussion}

The main picture to emerge from these commentaries was that in the case of objectives, varieties of objectives were planned in the courses. In some courses, developing students' knowledge of listening skills and strategies were of paramount importance, Whilst, in the other courses, objectives such as vocabulary learning through listening, developing academic listening, practicing pronunciation and interaction were significant. With regard to the nature of listening and the processes required to undertake the listening tasks in the courses, a divergence was found between bottom-up and top-down types of processing. Some of courses based their listening practices on equipping students with the ability of literal and sentence-level understanding of the material; on the other hand, other courses were designed based on the interpretive skills of comprehension. Along with variation in the nature of listening on courses, a fair amount of divergence was observed regarding the amount and types of listening prescribed in each listening course. The differences identified were primarily between courses and some courses devoted their class time to listening more than the other courses, whereas in the other courses inside-the class listening kept to minimum and most of listening practices were set as out of the class homework. Since the listening courses were the integration of listening with speaking together, the requirement of integration was obvious in the courses investigated. Beside the integration with speaking, integration with other skills, reading and writing was also identified. Finally, at the last area investigated, the analysis of the commentaries suggested that listening practice was changed through the time in line with the changes in students' needs according to their social, educational and other contexts.

\section{Conclusion}

The results of the analysis of the interviews indicate the paramount importance of listening in the academic context, especially as a common thread for getting information on various subjects on the courses. For some of the courses, developing the skills needed for listening was of paramount importance, whereas for the other courses the ability to listen to the varieties of English and the development of interactional competence was of significant prominence. The analysis of the interviews regarding the nature of listening revealed a fair amount of variation in the perceptions of academics across the listening courses. The more academic English - oriented lecturers, attested the utility of more interpretive ways of coping with listening input. Whilst others, the more general English - oriented instructors, insisted on the combination of both bottom up and top-down ways of processing listening stimuli. Along with variation in the nature of listening on courses, a fair amount of discrepancy was noted regarding the amount and types of listening prescribed in each listening course. The differences perceived here were mainly between courses. Such differences were quite noticeable, for example, in the quantity of listening anticipated from listeners. In some listening courses, instructors spoke of the need for students to do 'substantial' listening on their courses, and generally to go beyond the set listening. A last area covered in the interviews was the consideration of changes in students' listening requirements and practices on their courses. Interestingly, the perceived changes commented by informants were a kind of transformation from one situation (or situations) to the other situation (or situations). With regard to the processes, the transformation of listening processes was from literal to interpretive forms as the course proceeds. In the case of the materials, the transformation of situations was of renovation kind from more textbook - oriented to more internet oriented view. The findings of the current study suggest some practical implications not only for the EFL students, but also for the EFL listening instructors. In this regard, the findings suggests that in order to be able to develop their listening ability, students not only need to equip themselves with more interpretive skills of listening, but also they are required to accustom themselves with more internet-oriented materials in their classes. On the other hand, listening instructors are also required to reconcile the challenges student face in encountering these transformations and create a balance between different types of skills and course materials in their classes according to their students' needs.

\section{References}

Alonso, S. (2012). The importance of teaching listening and speaking skills. MA thesis. Convocatoria de Junio.

Bacon, S. (1992). The relationship between gender, comprehension, processing, strategies, and cognitive and affective response in foreign language listening. The Modern Language Journal, 76, 160-178.

Buck, G. (2001). Assessing listening. New York: Cambridge University Press.

Chaudron, C. (1995). Academic listening. In D. J. Mendelsohn \& J. Rubin (Eds.), A guide to the teaching of second language listening (pp. 77-96). San Diego: Dominie.

Chaudron, C., Loschky, L., \& Cook, J. (1994). Second language listening comprehension and lecture note-taking. In J. Flowerdew (Ed.), Academic listening: Research perspectives (pp. 75-92). New York: Cambridge University Press.

Dornyei, Z. (2007). Research methods in applied linguistics. Oxford: Oxford university press. (Chapter 2)

Dunkel, P. A. (1988). The content of L1 and L2 students' lecture notes and its relation to test performance. TESOL Quarterly. 22, 259-281. 
Dudley-Evans, T. (1994). Variations in the discourse patterns favored by different disciplines and their pedagogical implications. In J. Flowerdew (Ed.), Academic listening: Research perspectives (pp. 146-158). New York: Cambridge University Press.

Erkaya, O. R. (2009). Plagiarism by Turkish Students: Causes and solutions. Asian EFL journal. 11(2), 86-103.

Retrieved from http: //www. Asianefljournal.com.

Flowerdew, J. (1994). Academic listening: Research perspectives. New York: Cambridge University Press.

Flowerdew, J., \& Miller, L. (1997). The teaching of academic listening comprehension and the question of authenticity. English for Specific Purposes. 16. 27-46

Griffiths, R. T. (1990). Speech rate and NNS comprehension: A preliminary study in time-benefit analysis. Language Learning. 40. 311-336.

Harmer, J. (1991). The practice of English language teaching. Essex: Longman Group UK Ltd.

Hansen, C. (1994). Topic identification in lecture discourse. In J. Flowerdew (Ed.), Academic listening: Research perspectives (pp. 131-145). New York: Cambridge University Press.

Imhof, M. (1998). What makes a good listener? Listening behavior in instructional settings. International Journal of Listening. 13. 81-105.

Iwankovitsch, R. (2001). The importance of listening. Language Arts Journal of Michigan. 17, (2). 4-6.

Jeon, J. (2007). A study of listening comprehension of academic lectures within the Construction-integration model. Unpublished Doctoral Dissertation, Ohio University, USA.

Lynch, T. (1995). The development of interactive listening strategies in second language academic settings. In D. J. Mendelsohn \& J. Rubin (Eds.), A guide to the teaching of second language listening (pp. 166-185). San Diego: Dominie.

Love, P. G., \& Simmons, J. (1998). Factors influencing chatting and plagiarism among graduate students in a college of education. College Students Journal. 33(4), 539 551. Retrieved from http: //web.ebscohost.com.

Malinovski, B. (1923). The problem of meaning in primitive languages. In C. Ogden \& I. Richards (Eds.), The Meaning of meaning. London: Kegan Paul.

Moore, T., Morton, J., and Price, S. (2012). Construct validity in the IELTS Academic Reading test: A comparison of reading requirements in IELTS test items and in university study. IELTS Research Reports, 11. IELTS Australia and British Council: Swinburne University.

Odell, L, Goswami, D and Herrington, A. (1983). The discourse-based interview: A procedure forexploring the tacit knowledge of writers in nonacademic settings. In L, T., Mosenthal and S. Walmsley (Eds), Research on writing: Principles and methods (pp 221-236). New York: Longman

O’Malley, J. M., Chamot, A. U., \& Kupper, L. (1989). Listening comprehension strategies in second language acquisition. Applied Linguistics, 10. 418-437.

Olsen, L. A., \& Huckin, T. N. (1990). Point-driven understanding in engineering lecture comprehension. English for Specific Purpose. 9. 33-47.

Power, D. E. (1986). Academic demands related to listening skills. Language Testing 3, 1-38.

Richards, J. C. (1983). Listening comprehension: Approach, design, procedure. TESOL Quarterly, 17, $219-240$.

Richards, J. C. (1985). The context of language teaching. Cambridge: Cambridge University Press.

Rost, M. (2011). Teaching and researching listening, New York: Pearson.

Smidt, E., \& Hegelheimer, V. (2004). Effects of online academic lectures on ESL listening comprehension, incidental vocabulary acquisition, and strategy use. Computer Assisted Language Learning. 17, 517-556.

Tauroza, S., \& Allison, D. (1994). Expectation-driven understandings in information systems lecture comprehension. In J. Flowerdew (Ed.), Academic listening: Research perspectives (pp. 35-54). New York: Cambridge University Press.

Vandergrift, L. (1996). The listening comprehension strategies of core French high school students. The Canadian Modern Language Review. 52, 200-223.

Young, L. (1994). University lectures-macro-structure and micro-structure. In J. Flowerdew (Ed.), Academic listening: Research perspectives (pp. 159-176). New York: Cambridge University Press.

Zhao, Y. (1997). The effects of listener's control of speech rate on second language comprehension. Applied Linguistics. 18. 49-68. 
Appendix: Semi - structured interview

\section{PART 1. Introduction (content, skills, general listening requirements)}

1. How would you describe the main content of the course you teach on?

2. What do you see as the course's main objectives regarding the skills/attributes to be developed in students?

3. How would you describe the general listening requirements for students on the course?

i. How much listening do students need to do?

ii. Are there weekly listening requirements?

iii. What sorts of materials do students need to listen?

iv. Are there any activities they need to complete when doing the weekly listening?

v. What purposes do you have for setting weekly listening for students?

vi. Have the listening requirements on your course changed over the years?

vii. What challenges generally do students face in handling listening requirements on the course? What about students from different language backgrounds?

\section{PART 2. Listening and Assessment tasks}

4. What are the main assessment tasks/activities you set for students on the subject taking each of these tasks at a time?

i. What do students need to do to successfully complete the task?

ii. How much listening is required to complete the task? How much material? What types of material?

iii. How would you describe the nature of the listening they need to do to successfully complete the task? (e.g., basic comprehension of material? Some form of interpretation?)

iv. What type of material from the listening would students need to include in the spoken and written assignment?

v. What challenges do students face in drawing on listening material for this assignment? Are there particular difficulties for students from different language backgrounds?

5. The following is a list of listening skills from Harmer (1990) and specific listening sub skills from Richards (1985) required of students in their academic study. All are important in some way - which ones would you see as being particularly important on your course? Explain? Are there any other important skills not included on the list?

Skills: Ability to...

- extract specific information

- get the general picture

- listen in order to perform a task

- conform expectations they have about a text

- comprehend class lectures

- take notes

- evaluate (what is relevant and what is redundant)

- follow instructions

- carry out tasks and

- $\quad$ interact with teachers and peers

Sub-skills: Ability to...

- $\quad$ identify purpose and scope of listening

- identify topic of lecture and to follow topic development

- identify relationships among units of discourse

- identify role of discourse markers

- infer relationships

- recognize the key lexical items related to subject/topic

- identify topic of lecture and to follow topic development

- recognize markers of cohesion

- recognize the function of intonation to signal information structure

- detect attitude of speaker toward subject matter

- follow different modes of lecturing

- follow lecture despite differences in accent and speed

- different styles of lecturing: formal, planned, unplanned 
- recognize irrelevant matters: jokes, digressions, meanderings

- recognize function of nonverbal clues as markers of emphasis and attitude and understand knowledge of classroom conventions

- recognize instructional/learner tasks (warnings, suggestions, recommendations, advice, and instructions). 